\title{
Recycling Strategies for Ceramic All-Solid-State Batteries-Part I: Study on Possible Treatments in Contrast to Li-Ion Battery Recycling
}

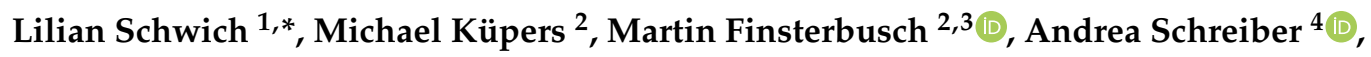 \\ Dina Fattakhova-Rohlfing ${ }^{2,3,5}$, Olivier Guillon ${ }^{2,3,6}$ and Bernd Friedrich ${ }^{1}$ (D) \\ 1 IME, Institute for Process Metallurgy and Metal Recycling, RWTH Aachen University, Intzestraße 3, \\ 52056 Aachen, Germany; bfriedrich@ime-aachen.de \\ 2 Forschungszentrum Jülich $\mathrm{GmbH}$, Institute of Energy and Climate Research (IEK-1): Materials Synthesis \\ and Processing, Wilhelm-Johnen-Straße, 52425 Julich, Germany; m.kuepers@fz-juelich.de (M.K.); \\ m.finsterbusch@fz-juelich.de (M.F.); d.fattakhova@fz-juelich.de (D.F.-R.); o.guillon@fz-juelich.de (O.G.) \\ 3 IEK-12, Forschungszentrum Jülich GmbH, 52425 Julich, Germany \\ 4 IEK-STE Forschungszentrum Jülich GmbH, 52425 Julich, Germany; a.schreiber@fz-juelich.de \\ 5 Faculty of Engineering and Center for Nanointegration Duisburg-Essen (CENIDE), \\ Universität Duisburg-Essen, Lotharstraße 1, 47057 Duisburg, Germany \\ 6 Jülich Aachen Research Alliance, JARA-Energy, 52425 Julich, Germany \\ * Correspondence: lschwich@ime-aachen.de; Tel.: +49-241-8095194
}

Received: 23 October 2020; Accepted: 14 November 2020; Published: 17 November 2020

\begin{abstract}
In the coming years, the demand for safe electrical energy storage devices with high energy density will increase drastically due to the electrification of the transportation sector and the need for stationary storage for renewable energies. Advanced battery concepts like all-solid-state batteries (ASBs) are considered one of the most promising candidates for future energy storage technologies. They offer several advantages over conventional Lithium-Ion Batteries (LIBs), especially with regard to stability, safety, and energy density. Hardly any recycling studies have been conducted, yet, but such examinations will play an important role when considering raw materials supply, sustainability of battery systems, $\mathrm{CO}_{2}$ footprint, and general strive towards a circular economy. Although different methods for recycling LIBs are already available, the transferability to ASBs is not straightforward due to differences in used materials and fabrication technologies, even if the chemistry does not change (e.g., Li-intercalation cathodes). Challenges in terms of the ceramic nature of the cell components and thus the necessity for specific recycling strategies are investigated here for the first time. As a major result, a recycling route based on inert shredding, a subsequent thermal treatment, and a sorting step is suggested, and transferring the extracted black mass to a dedicated hydrometallurgical recycling process is proposed. The hydrometallurgical approach is split into two scenarios differing in terms of solubility of the ASB-battery components. Hence, developing a full recycling concept is reached by this study, which will be experimentally examined in future research.
\end{abstract}

Keywords: battery recycling; all-solid-state batteries; metallurgical recycling; metal recovery; recycling efficiency

\section{Introduction}

Generally, continued operation of batteries after their typical end of life (80\% of nominal capacity), often referred to as "second life", has both environmental and economic benefits. However, due to required testing protocols and safety as well as reliability issues, this second life exploitation is challenging [1]. At the end of the first or the second life, normal recycling needs to be exploited to 
lower environmental impact of battery fabrication and move further towards a circular economy. The recycling of LIBs is already established on the industrial scale using specific process routes [2]. The following section provides an overview on possible recycling paths. However, many more processes are investigated in both industry and research, so this elaboration is an overview and not full literature review. Moreover, in the following section, industry and research activities are not differentiated, as the focus will be presenting options for Li-Ion battery recycling and hence, their possible application to ASBs. The most direct way to reuse battery materials is by reconditioning the active materials for direct fabrication of new cells [2]. If this is not possible (e.g., due to cell performance), elemental recycling strategies based on the combination of two different process modules are in place: Pre-treatments and metal extraction processes [3].

Within pre-treatments, discharging is crucial to safely process the batteries further. This can be realized by immersing the used battery into a salt solution [4] or by a thermal treatment, e.g., a pyrolysis, as a deactivation step [5]. During this thermal pre-treatment, organics and binders are decomposed and evaporated, leaving the reactor via the off-gas stream [6]. The applied thermal treatment can either occur by generating an inert gas or vacuum atmosphere, thus in an oxygen-free environment (pyrolysis), or in oxygen-containing environment (incineration/thermolysis) [4,7]. After completing the thermal treatment, a mechanical treatment consisting of comminution and separation is possible. The separation can be realized by making use of physical properties or a sieving operation [8]. An alternative sequence is the deactivation of the batteries in a salt solution, a mechanical treatment, and a subsequent thermal treatment [9-12]. Here, before the thermal treatment, the batteries are either shredded and then sorted by means of physical properties [10], or directly manually dismantled to extract specifically the electrode foils with the attached active mass [9,12]. A third method combines inert/cryogenic shredding and a subsequent thermal treatment [13]. This brief overview gives the three main approaches regarding pre-treatment steps. There are differences in applied atmospheres and temperatures, but in most cases, a better removability of black mass, especially on the cathode side, from substrate foils is reported when applying a thermal treatment. This can be explained considering the following: Within battery design, a good adhesion between substrate foils and active materials is crucial, which is realized by applying a strong binder. The binder compounds can be cracked and removed in the thermal treatment. Moreover, the removal of the binder and other organics is a suitable tool for easing the downstream hydrometallurgical treatments, since the organic compounds are hardly soluble in leaching steps [7,12]. On the other hand, a challenge in direct shredding and in thermal pre-treatment is the need for extensive off-gas cleaning [4,14].

Within the metal extraction, there are different chemical approaches, such as hydrometallurgy and pyrometallurgy [15]. Hydrometallurgical processes offer many different solvents for leaching and also target phases of the battery components. They can be classified by the type of leaching media: Mineral acids, alkalis, and organic acids. For instance, processes based on mineral acids, such as sulfuric acid $\left(\mathrm{H}_{2} \mathrm{SO}_{4}\right)$ or hydrochloric acid $(\mathrm{HCl})$, or organic acids, such as ascorbic acid together with hydrogen peroxide $\left(\mathrm{H}_{2} \mathrm{O}_{2}\right)$, have reached satisfying yields [16]. Altogether, hydrometallurgy requires less energy, and due to its selectivity high purities can be obtained. Nonetheless, mechanical and/or thermal pre-treatments are essential [14].

Pyrometallurgy generally is a high efficient concentration operation and comprises of the smelting of batteries transferring noble metals to an alloy, which then will be purified by hydrometallurgical refining steps $[14,17]$. Rather ignoble, and depending on the operation temperatures, partly volatile metals will be transferred to a slag phase or a flue dust [18]. This path is industrially widely applied [18] due to its high robustness and productivity [19]. In addition, pyrometallurgy is robust regarding the input stream's heterogeneity, which is why battery scrap can be treated along with persisting primary production lines of metals like cobalt (Co) [20]. Since lithium (Li) cannot be recovered by pyrometallurgical methods as metal, a downstream slag purification by means of hydrometallurgy is also a subject of research [21]. 
In conclusion, different process modules can be combined to design the most effective recycling process for each cell design and, vice versa, cell can be designed to promote effective recycling.

The main scrap volumes of LIBs recycling are presently based on consumer batteries, and partly also on Hybrid Electric Vehicles/ Electric Vehicles (HEV/EV) traction batteries [22]. The EV scrap volumes that are available for recycling are comparatively low, but if this status-quo changes in the future towards an increased use of electrification in the mobility sector, some recycling paths will turn out to be more viable if they benefit from scale effects [2]. Today's industrial recycling paths focus mainly on the valuable elements; however, LIBs are complex and materials from different applications or generations are often accompanied by changing compositions [22,23]. Since the second life application rates are currently very low in industrial processes [24], a lot of research activity is pursued targeting elemental materials' recycling. Public-funded German projects such as MERCATOR or InnoRec tend to follow innovative recycling steps in order to mobilize $\mathrm{Li}$, and even in the case of MERCATOR, the critical raw material graphite will be reused for non-battery applications [25,26]. Methods for mobilizing Li before it is deposited in a slag or flue dust are already under fundamental investigation. These investigations are relevant since extracting Li from a slag is energy and resource intensive, and the current Li price does not assure economic viability for this add-on process [20]. Early-stage recovery methods for transforming of Li phases in the battery active mass are proposed, making use of supercritical $\mathrm{CO}_{2}$ or by thermally activation [27-30]. Innovative methods for a holistic recycling based on graphite pursue the flotation technology [31,32]. Another important research topic is the recovery of the electrolyte, which is challenging due to its high reactivity [33] and the ecotoxicity of prevailing F-compounds [34]. Phosphorous (P), present in almost all LIBs, is another critical topic in recycling. P needs to be removed in pyrometallurgical nickel (Ni) production since it affects the properties of specific $\mathrm{Ni}$ alloys [35]. In conclusion, there is still a strong need for research in recycling of conventional batteries [36], especially based on recycling efficiency and added value. Moreover, research on non-chemical recycling optimization is needed, for example in the field of collection and scrap logistics [2].

ASBs are regarded as promising future batteries, as they have advantages like enhanced stability, safety, and energy density over conventional LIBs [37]. This is mainly due to the solid electrolyte's beneficial properties such as a better thermal stability, non-flammability, resistance against overcharging, and long cycle stability [38].

Different classes of solid-state electrolyte materials like polymers, sulfides, and oxides are under investigation. Due to easier processing, polymer based ASBs are the closest system in terms of market introduction. Sulfides are also easy to process and show the highest Li-ion conductivity, increasing the power density greatly, but their difficult synthesis and chemical instability towards water/air impede the large-scale fabrication. Considering safety aspects, oxide-ceramic materials stand above all other $\mathrm{Li}$ electrolytes due to their chemical, thermal, and oxidation stability. They are non-flammable, non-toxic, and can be handled in air. The chemical stability of garnet-based $\mathrm{Li}_{7} \mathrm{La}_{3} \mathrm{Zr}_{2} \mathrm{O}_{12}$ electrolytes towards $\mathrm{Li}$ allows the direct use of metallic $\mathrm{Li}$, making this material one of the most promising electrolytes for ceramic all solid-state batteries [39]. However, expensive dopant elements like lanthanum (La) and tantalum (Ta) as well as the required high temperature processing steps are the biggest hurdles for large scale market introduction. Additionally, a first analysis of the resource availability have shown that with a market share of $10 \%$ in traction and stationary applications, $\mathrm{Li}, \mathrm{La}$ and zirconium $(\mathrm{Zr}) \mathrm{can}$ be classified as critical [40]. However, there is no general consensus on the assessment of resource availability and criticality of raw materials. Different studies evaluate the criticality of materials (especially Li) in different ways and with different results [41-49]. For example, Helbig et al. published a study to assess the supply risks associated with 10 elements used in different LIBs [45]. Li and Co have the highest supply risk scores. The high score for Li mainly emerges from a lack of end-of-life recycling and the high future technology demand. The high supply risk score of $\mathrm{Co}$, in contrast, results from the by-product dependence and the high risk from political instability. Aluminium (Al) shows the lowest supply risk score followed by titanium $(\mathrm{Ti})$, copper $(\mathrm{Cu})$, iron, $\mathrm{Ni}$, graphite, 
manganese (Mn), and P. Schultz and Kuckshinrichs [50] analyzed the need for Li for electrochemical energy storages. By analyzing data from known Li sources, the authors conclude that there is no major risk in terms of exhausting world reserves, especially if a market for Li recycling is introduced. However, with possible strongly rising demand in mind, the authors see serious potential for risks on the supply side, which may result in temporary shortage situations and rising price levels at the Li world market. The European Commission [48] identified 26 raw materials and material groups as critical. This includes $\mathrm{Co}$, La, phosphate rock, and Ta, which are used for ASBs. Li, Mn, Ni, Ti, Al, and $\mathrm{Cu}$ are considered non-critical according to the EU critical material list with $\mathrm{Li}$ and Mn being close to the threshold.

Moreover, a consideration of possible recycling processes was not part of the study by Troy et al. [40]. Generally, no recycling concepts for ceramic ASBs are in place yet. In an indirect way, Piana et al. investigated the reusability of industrial waste products for the synthesis of a sodium (Na)-on ASB electrolyte [51], and Wang et al. extracted end-of-life $\mathrm{LiMn}_{2} \mathrm{O}_{4}$ cathodes for resynthesizing a Li-Ion ASB electrolyte [52]. This shows that only rudimentary knowledge regarding a circular economy of ASBs exist. Therefore, this study aims to generate the first ceramic ASB recycling concept. In particular, a theoretical approach is chosen, taking the presented LIB treatment methods as a starting point, then evaluating to what extent specific tools can be translated to ASB recycling.

\section{Materials and Methods}

\subsection{Cell Concept}

In terms of industrial and technological value, the cell concept with the lowest cost and highest energy density for oxide-ceramic based ASBs is a flat cell, which is housed in a pouch bag. The design of the cell itself (see Figure 1) is rather simple and consists of five different layers: (1) Anode, (2) Separator, (3) Cathode, (4), and (5) Current Collectors.

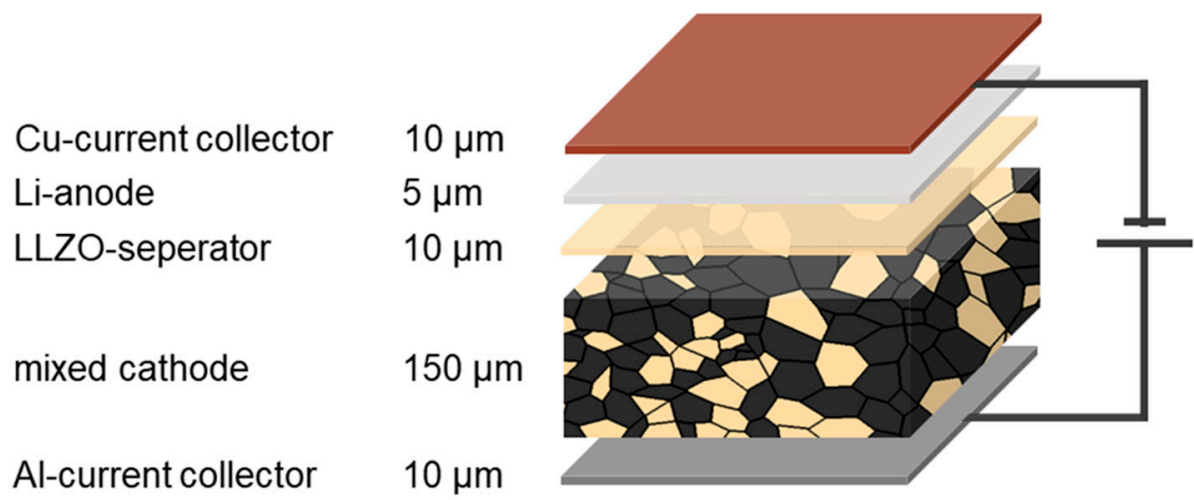

Figure 1. Pouch cell design of a ceramic ASB: A thick mixed cathode is separated by a thin LLZ-layer from the Li-metal anode. The currents are collected by a thin $\mathrm{Cu}$ or $\mathrm{Al}$ foil.

(1) Anode: The electrochemical stability of some oxide-ceramic electrolytes towards metallic Li allows for the direct use of Li metal as an anode material. Li metal shows a very high theoretical capacity and the lowest electrochemical potential, making it the most promising anode material in Li based batteries in terms of energy density. Theoretically, all active Li ions are located in the cathode material. Nevertheless, a thin layer of metallic $\mathrm{Li}$ on the anode side is necessary to compensate for irreversible Li losses and a homogeneous Li plating during cycling. Thus, we used a thin layer of $5 \mu \mathrm{m}$ thickness in our cell design, knowing that Li free anode concepts are also heavily researched at the moment.

(2) The separator prevents electrical short circuiting due to the direct contact between anode and cathode material, while it allows Li-ions to pass between the two electrodes. In ASBs, the separator can be made from the solid electrolyte itself, therefore having the same high ionic conductivity while 
the electronic conductivity is low. However, it needs to be chemically stable towards the anode material (Li metal) on the one hand and towards the cathode material (e.g., LCO, NMC) on the other hand. So far, the only materials that combines all these properties are garnet-based compounds like $\mathrm{Li}_{7} \mathrm{La}_{3} \mathrm{Zr}_{2} \mathrm{O}_{12}$ (LLZ). Ta substitution $\left(\mathrm{Li}_{6.4} \mathrm{La}_{3} \mathrm{Zr}_{1.6} \mathrm{Ta}_{0.4} \mathrm{O}_{12}\right)$ stabilizes a cubic garnet structure and enhances the conductivity of the material up to $1 \mathrm{~ms} / \mathrm{cm}$ [53]. Since the separator is an inactive part of the battery, it should be as thin as possible while still showing sufficient electronic and mechanical properties. A dense layer of $10 \mu \mathrm{m}$ LLZ is used as a compromise between total resistance, sufficient mechanical properties, and realistic processing. In the future, thinner separators and interlayer to improve the contact resistance are of course realistic.

(3) Cathode: In a conventional LIB, the cathode consists of a rather porous structure of active material, conductive additives, and polymer binders in which the liquid electrolyte can be infiltrated and achieves a good interface contact. As cathode active materials (CAM) for ASBs, the same materials which are already used in LIB can be incorporated. To achieve a good surface contact between the two solid phases, the cathode material needs to be co-sintered together with the electrolyte. One promising material combination for oxide-based ASBs is the combination of $\mathrm{LiCoO}_{2}$ (LCO) and LLZ. The mixture of these materials is chemically stable up to $1085^{\circ} \mathrm{C}$ [54], which allows a co-sintering of the cathode. Batteries of this material mixture are already realized on lab scale [1,12,39,55]. However, to obtain high-energy density cells, the amount of CAM in the mixed electrode should be as high as possible. In our concept, we consider a CAM: solid electrolyte ratio of 2:1 as reasonable, allowing for percolation of both phases. The thickness of the cathode is set to $150 \mu \mathrm{m}$ to achieve areal capacities of approx. $4 \mathrm{mAh} / \mathrm{cm}^{2}$, which is a common value for conventional LIBs. By substituting Co in LCO by Ni and Mn the capacity of the cathode material can be increased. Therefore, we also consider the use of $\mathrm{LiNi}_{0.8} \mathrm{Mn}_{0.1} \mathrm{Co}_{0.1} \mathrm{O}_{2}$ (NMC811) in an ASB although this material shows a lower chemical stability at elevated temperatures towards LLZ then LCO [56]. However, stabilizing coatings or lowering the sintering temperatures by advanced processing technologies could allow for usage of NMC811 as cathode material for LLZ bases ASBs in the future. To further increase energy density, another highly conductive ceramic electrolyte should be considered: NASICON structure based $\mathrm{Li}_{1.5} \mathrm{Al}_{0.5} \mathrm{Ti}_{1.5}\left(\mathrm{PO}_{4}\right)_{4}(\mathrm{LATP})$. It shows a comparable or even higher total Li-ion conductivity $(\sim 1 \mathrm{~ms} / \mathrm{cm})$ than LLZ, while the density is lower and the raw materials needed for synthesis are less critical and cheaper [57]. However, the major drawback is its lower chemical stability, especially towards metallic Li. Without any stabilizing coating, it can therefore not be used as a separator material. To combine both advantages of the individual materials, we also investigate a cell concept with LLZ as separator and LATP instead of LLZ in the mixed cathode [58].

(4) Current collector anode side: the current collector on the anode side needs to fulfill only two requirements: high electronic conductivity and chemical stability towards metallic Li. One material that fulfills these requirements is $\mathrm{Cu}$. Since the ceramic cathode and separator material construct a mechanically stable backbone, a rather thin layer of $\mathrm{Cu}(10 \mu \mathrm{m})$ is sufficient.

(5) Current collector cathode side: Since the cathode side is chemical less active then the anode side, the requirements for the current collector on the cathode side are reduced to only high electronic conductivity. To keep the cell as light as possible, we use a thin Al foil (10 $\mu \mathrm{m})$ on this side.

Due to the mechanical stability of the cell stemming from the ceramic cell itself, the thicknesses of the $\mathrm{Cu}$ and $\mathrm{Al}$ current collectors could be decreased further (even only the metallic Li could be used as current collector on the anode side). However, since this will depend mainly on the specific production process and design of the cell stacks (e.g., bi-polar vs. parallel), all possible variations cannot be investigated within this paper.

In total, we consider four different cell designs of promising as future ceramic ASBs, all containing a LLZ separator, $\mathrm{Cu}$ and $\mathrm{Al}$ current collectors, but different cathode composite materials. The energy density of these four cell designs were calculated and are listed in Table 1.

The LATP-based cells (2.1 and 2.2) generally show higher energy densities, stemming from its lower density compared to LLZ. NMC811 with its higher capacity than LCO results in the highest total energy densities. 
Table 1. Capacities of the four different cell designs.

\begin{tabular}{ccc}
\hline Cell Number & Cathode Materials & Energy Density $\mathbf{( W h} / \mathbf{k g})$ \\
\hline 1.1 & LLZ + LCO & 309 \\
1.2 & LLZ + NMC & 406 \\
2.1 & LATP + LCO & 352 \\
2.2 & LATP + NMC & 463 \\
\hline
\end{tabular}

\subsection{Assembling Process}

One crucial step during the assembling of a working cell is to ensure a good interface conductivity between the separator and the cathode material. This can be achieved by a co-sintering process, where the cathode and the separator will be baked together at elevated temperatures. The current collectors, on the other hand, will be attached rather loose on the electrodes and mainly kept in place by the packaging of the cell. The cell housing itself will most likely be adapted from LIBs in pouch cell format, since it has the lowest impact on the energy density and enables the use of the same foil, tabs, and ultrasonic welding to obtain cell stacks and batteries. After the sintering process, cathode and separator will be chemically bonded, making a mechanical separation impossible. However, due to the brittle nature of ceramics, crack formation is still a major concern. The Li anode will be either pressed on the separator as a foil or, more likely, will be evaporated on the separator material. Cycling and the ductility of Li metal will make it hard to mechanically separate the anode from the rest of the cell.

\subsection{Material Demand}

The market for batteries will increase drastically within the next years. With politics pushing worldwide towards an electrification of the automobile sector, the demand for batteries will multiply within the next years, from $500 \mathrm{GWh}$ in 2017 to several TWh in 2050 [59]. Considering our four cell concepts, we calculated the amount of raw material that would be necessary to produce $1 \mathrm{TWh}$ of oxide-based ASB.

To discuss possible bottlenecks in supply of the elements for the assumed 1 TWh ASB application, we present the material requirements in comparison to the current world production as a first rough estimate (Table 2).

The material compositions (weight percent) of all four ASB cells are shown in Figure 2. Around one-third of the cell consists of transition metals from the cathode side containing $\mathrm{Co}$, $\mathrm{Ni}$, and Mn. The electrolyte metals in the LLZ cells (1.1 and 1.2) make around one quarter of the complete cell, with the main part being the rare earth element La. $10 \mathrm{wt} . \%$ is $\mathrm{Cu}$, while Li makes up around $6 \mathrm{wt} . \%$. The total demand of the materials that are necessary for a battery production of $1 \mathrm{TWh}$ is listed in Table 2. The right side of the table shows the share (\%) on current world production for $1 \mathrm{TWh}$. All four cell types require a critical demand of $\mathrm{Li}, \mathrm{La}$, and Ta. In addition, the Co and zirconia demand can be seen as critical for cell 1.1,1.2, and 2.1. The criticality can be defused when using Co pure cathode material NMC as it is in cell 1.2 and 2.2, since Ni and Mn can be seen less critical. Looking at the LLZ-based batteries, the demand of La, Zr and especially Ta are in a range that goes far beyond the current world production. Including LATP into the mixed cathode (Cell 2.1 and 2.2) lowers the criticality for $\mathrm{La}, \mathrm{Zr}$, and $\mathrm{Ta}$, but being still in a critical range for $\mathrm{Ta}$ and $\mathrm{La}$. This shows that a good recyclability of the battery cells is inevitable, if this type of batteries should take a reasonable market share. However, any future developments in the raw material production market are not taken into account yet and can change the results noticeably. It is very likely that as demand increases, new mines will start production and others will maximize their output [40].

The following table shows battery components and their annual production, and relates those numbers to the material demand when producing the cells presented in this study (see Figure 2 and Table 2). 


\section{Cell 1.1: LLZ + LCO}

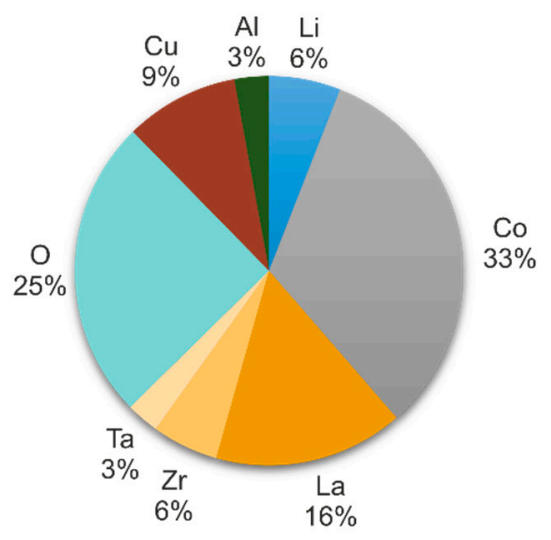

Cell 2.1: LATP + LCO

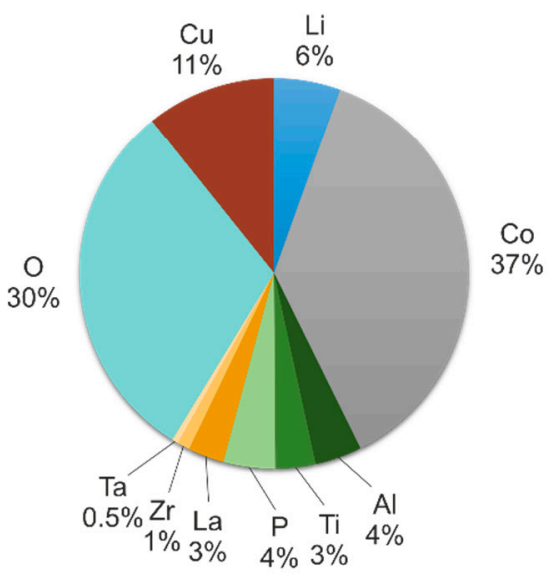

\section{Cell 1.2: LLZ + NMC}

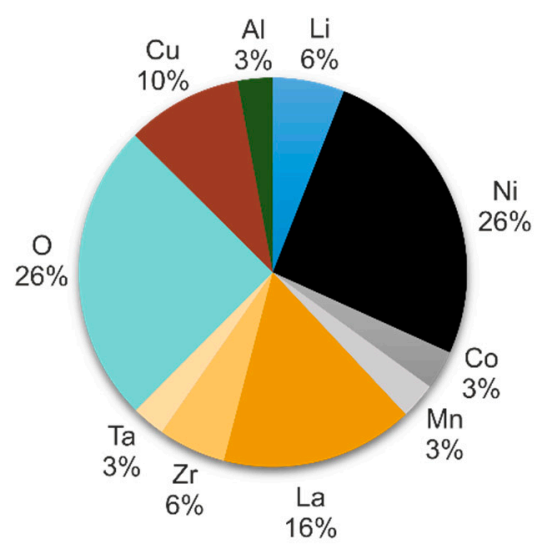

Cell 2.2: LATP + NMC

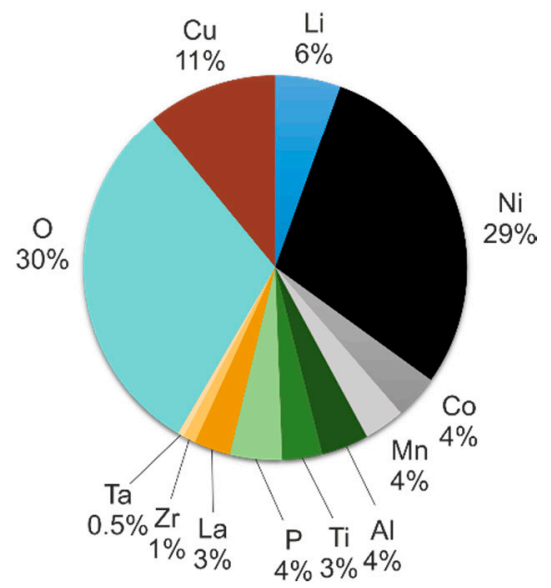

Figure 2. Material compositions of the four different cell designs.

Table 2. Material demand required for 1 TWh ASB and share of demand on current world production.

\begin{tabular}{|c|c|c|c|c|c|c|c|c|c|}
\hline & \multirow[t]{2}{*}{ World Production (T) } & \multicolumn{4}{|c|}{ Material Demand for $1 \mathrm{TWh}$ ASB in $10^{5} \mathrm{~T}$} & \multicolumn{4}{|c|}{$\begin{array}{l}\text { Share }(\%) \text { on Current World Production } \\
\text { in } 2030\end{array}$} \\
\hline & & Cell 1.1 & Cell 1.2 & Cell 2.1 & Cell 2.2 & Cell 1.1 & Cell 1.2 & Cell 2.1 & Cell 2.2 \\
\hline LI & $77,000[60]$ & 1.93 & 1.47 & 1.57 & 1.19 & 251 & 191 & 204 & 155 \\
\hline NI & $2,700,000[60]$ & - & 6.35 & - & 6.35 & - & 24 & - & 24 \\
\hline $\mathrm{CO}$ & $140,000[60]$ & 10.56 & 0.80 & 10.56 & 0.80 & 755 & 57 & 754 & 57 \\
\hline $\mathrm{MN}$ & $\begin{array}{c}15,414,509[61] \\
53,000,000^{\text {a }}[62]\end{array}$ & - & 0.74 & - & 0.74 & - & 0.5 & - & 0.5 \\
\hline $\mathrm{AL}$ & $64,000,000[60]$ & 0.93 & 0.72 & 1.11 & 0.86 & 0.1 & 0.1 & 0.2 & 0.1 \\
\hline $\mathrm{TI}$ & $4,394,500[62]$ & - & - & 0.95 & 0.73 & - & - & 2.2 & 1.7 \\
\hline $\mathrm{P}$ & $36,650,402[61]$ & - & - & 1.23 & 0.95 & - & - & 0.34 & 0.26 \\
\hline LA & $56,700^{\mathrm{b}}[60]$ & 5.11 & 3.95 & 0.85 & 0.66 & 901 & 697 & 150 & 116 \\
\hline ZR & $112,471^{\mathrm{c}}[62]$ & 1.79 & 1.39 & 0.30 & 0.23 & 159 & 123 & 27 & 20 \\
\hline TA & $1800[60]$ & 0.89 & 0.69 & 0.15 & 0.11 & 4928 & 3816 & 833 & 611 \\
\hline $\mathrm{CU}$ & $20,000,000[60]$ & 3.07 & 2.38 & 3.07 & 2.38 & 1.5 & 1.2 & 1.5 & 1.2 \\
\hline
\end{tabular}

${ }^{\mathrm{a}} \mathrm{Mn}$ ore; ${ }^{\mathrm{b}}$ La production accounts for $27 \%$ of the total world rare earth production of 210,000 T [63]; ${ }^{\mathrm{c}}$ based on

$1,256,000 \mathrm{~T} \mathrm{ZrSiO}_{4}$, (zircon), assumption: $18 \%$ of the total zircon amount is used for zirconia production $\left(\mathrm{ZrO}_{2}\right)$.

\section{Recycling Approach}

A battery recycling process should be tailored to the battery components used and relevant elements targeted for recovery. As indicated before, many different ASB systems are promoted currently in laboratories all over the world. Moreover, within the three superordinate systems 
(polymers, sulfides, and oxides), various components are being tested during the cell design phase aiming at a high-performance solid-state battery. Therefore, exemplarily battery compositions have to be selected for generating first ASBs recycling considerations. In this study, recycling approaches for the two systems LLZ + NMC and LATP + NMC are designed to match the different available systems. These approaches are then compared in terms of their sustainability.

Due to the different nature of both composition and physical form of ASBs, the recycling concepts also differ quite a lot from those for conventional LIBs: Most integral components of the cell are chemically rather ignoble, and besides, do not show a high vapor pressure. ASBs do not contain combustible components, and thus, do not contribute to exothermic reactions. Hence, pyrometallurgy-based recycling steps are not the tool of choice for establishing a suitable recycling process, such avoiding the generation of only a large volume of slags. Moreover, the ASB composition according to Figure 2 shows that the battery system contains even more elements in comparison to conventional LIBs, leading to a more complex recycling chain. Regarding ecotoxicity, ASBs have beneficial properties for performing a recycling process. They do not contain fluorine or phosphorous compounds, which is why the amount of hazardous gas phases will be reduced when applying a thermal treatment. According to the state-of-the-art of LIBs recycling (see Introduction), the occurrence of hazardous off-gases is one main drawback of thermal pre-treatments. Recycling is generally eased due to the absence of organic compounds, like binders. They are removed by sintering in the battery production.

In order to select a suitable recycling process, Figure 3 sums up the Introduction chapter. Here, the reference level comprises of charged battery cells, assuming that they have already been extracted from their modules in case of EV-battery packs. Even though a discharge of whole modules is possible, for reasons of clarity, this option is neglected in this case.

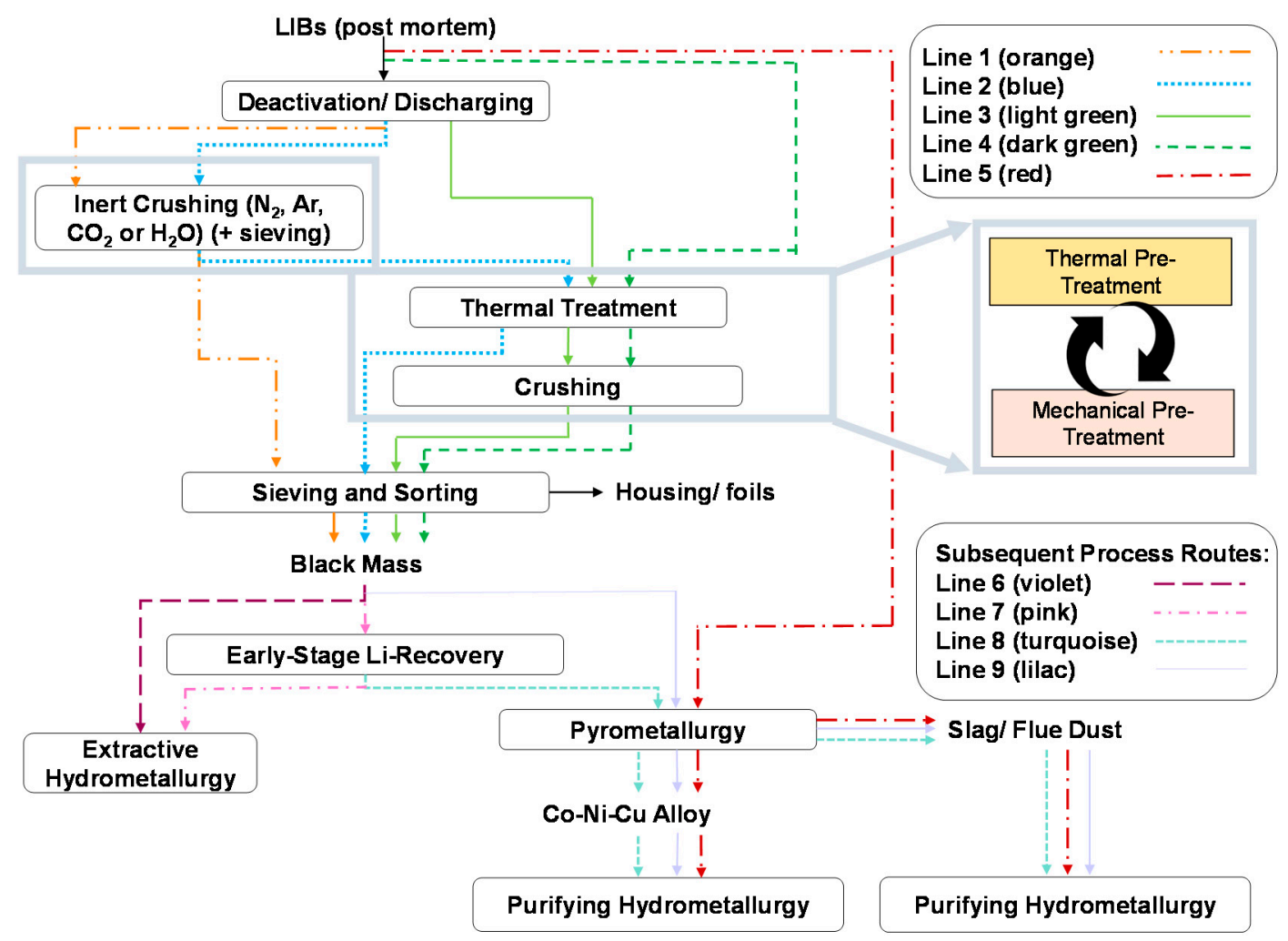

Figure 3. Options for selecting a recycling method based on the available recycling paths according to the state-of-the-art. 
As described above, Line 5 (red path, pyrometallurgy) is not seen as optimal treatment. Besides, since ASBs are beneficial for safety and risk for fire incidents, the selection of pre-treatments is more flexible in terms of direct inert or aqueous shredding (Lines 1 and 2). The pre-treatment or LIBs generally requires a discharge step to protect the comminuting unit operations from fire incidents, a thermal treatment with discharging (Line 3), or a direct thermal treatment without discharging (Lines 4 and 5). In Line 4, a thermal treatment can by bypassed due to a robust system being able to handle thermal runaways and moreover comprising a waste heat recovery system. In Line 5, a thermal treatment can by bypassed due to the high temperature requirements in smelters, where thermal runaways do not represent a processing challenge. For ASBs, either Line 1 or 2 is preferred since the solid-state battery components are sintered and thus are expected to be mechanically and chemically stable. Inert shredding in $\mathrm{H}_{2} \mathrm{O}$ can be beneficial for the ASBs treated in this study, since their anodes do not consist of metallic lithium, which is highly reactive and thus could go up in flames. Hence, high costs for vacuum and inert gas shredding could be avoided by aqueous shredding. Since no binders are applied, a thermal treatment is not necessarily required for ASBs. It has been, however, reported in the literature that an eased component liberation is reached when applying a thermal treatment. Thus, whether Line 1 or 2 is beneficial is to be examined in Part II of this study. Whether the sintered battery components can be separated from one another can only be figured out by conducting practical experiments. Because of the comparatively high Li contents $(\sim 3 \mathrm{wt}$. $\% \mathrm{Li}$ in LIBs [64]) in comparison to $6 \mathrm{wt}$ \% $\mathrm{Li}$ in the ASBs (see Figure 2), a treatment for an Early-Stage Li-Recovery (ESLR) would be more viable, and thus, seems a good option for the selected concept. Finally, extractive hydrometallurgy is highly selective and can separate battery components like Mn, La, and Zr element-wise, which is why Line 7 (violet) or Line 8 (pink) are chosen for a subsequent process route. Whether ESLR is a suitable tool for ASBs is to be investigated experimentally in Part II of this study.

According to this discussion and based on know-how regarding hydrometallurgical extraction processes for recycling LIBs, as can be seen in $[8,18,65]$, the resulting flow chart for LLZ + NMC batteries can be seen in Figure 4 .

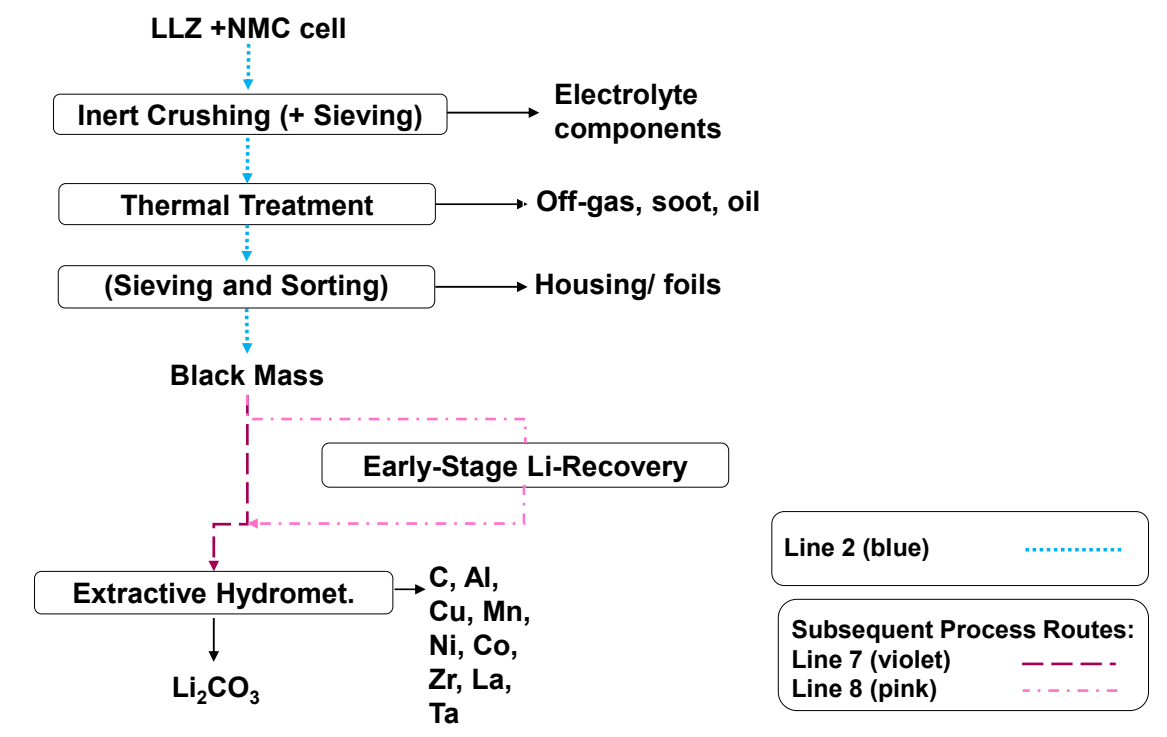

Figure 4. Experimental plan for a suitable LLZ + NMC recycling. C represents both graphite, active charcoal, and soot.

It has to be further examined whether a shredding process together with a component separation by means of sieving will lead to satisfying results. Eventually, a further comminution step by a ball mill is required to grind the oxidic fractions and liberate them from the substrate foils and casing. 
Moreover, research will be necessary considering the necessity of a thermal treatment. The ESLR, represented by a thermal or $\mathrm{CO}_{2}$-driven phase transformation of Li compounds into water soluble $\mathrm{Li}$-carbonate, and the subsequent dissolution of Li phases in $\mathrm{H}_{2} \mathrm{O}$ as a neutral leach is one option. Here, $\mathrm{Li}$, which will be dissolved, can be separated from the residual active mass, which is mainly insoluble in water. The $\mathrm{CO}_{2}$-driven option for the ESLR consists of a phase transformation by means of supercritical $\mathrm{CO}_{2}$ in an autoclave reactor filled with water or by gaseous $\mathrm{CO}_{2}$ in an aqueous medium. When using an autoclave reactor, an excess pressure of 73.8 bar [66] is needed to reach the supercritical state.

The above-mentioned garnet structure (LLZ) is a mineral compound, whose dissolution conditions are not experimentally proven yet. According to own studies, elevated temperatures and strong acids/bases are required to dissolve sintered LLZ. On this account, two scenarios are to be discussed within this study. They discuss the two border cases, in which either the whole LLZ structure is chemically dissolved (scenario 1) or only Li is dissolved from the structure, whereas the main garnet structure remains insoluble (scenario 2). In these scenarios, the underlying solvent is not further specified. However, it can be predicted that the solvent in scenario 1 will tend to be stronger than the used solvent in scenario 2 , since the $\mathrm{Li}^{+} / \mathrm{H}^{+}$exchange reaction is well investigated for LLT [67-69]. Both scenarios are presented in Table 3.

Table 3. Two hydrometallurgical recycling scenarios discussed within this study.

\begin{tabular}{lll}
\hline \multicolumn{1}{c}{ Criteria of Scenario } & \multicolumn{1}{c}{ Scenario 1 } & \multicolumn{1}{c}{ Scenario 2 } \\
\hline Characteristics & LLZ is fully dissolved & $\begin{array}{l}\text { Only Li is dissolved, the other LLZ } \\
\text { components remain solid } \\
\text { Leaching conditions }\end{array}$ \\
$\begin{array}{l}\text { High temperature/aggressive } \\
\text { leaching }\end{array}$ & Moderate leaching \\
\hline
\end{tabular}

The extractive hydrometallurgy according to Wang $[18,65]$ can be modified adding specific precipitation steps for $\mathrm{La}, \mathrm{Zr}$, and Ta. Depending on the scenario, the multistep hydrometallurgy is to be designed differently. In scenario 1, the elements $\mathrm{Zr}$, Ta, and $\mathrm{La}$ are integrated in the leaching and precipitation sequences according to their behavior in aqueous solutions. In scenario 2 , they are extracted as a concentrate. Here, no dissolution is taking place and cross-contaminations by similar precipitation areas, e.g., Co, is neglected. The following elaboration treats the behavior of $\mathrm{Zr}$, $\mathrm{Ta}$, and $\mathrm{La}$ in aqueous systems. For this purpose, both StabCal simulations and literature-based properties are considered. The StabCal simulations show the precipitation behavior in the case of ionic dissolution of $\mathrm{Zr}$, Ta, and La. This means that no information on the degree of dissolution is given. Moreover, the oxidation states of the input material cannot be specified by the StabCal simulations since the level of consideration is the ionic dissolution. The concentration applied refers to the chemical composition given, and the StabCal database used is indicated in the image captions. However, it has to be noted that no specification on leaching medium, $\mathrm{pH}$-additive and further components in the system can be detailed. When realizing the presented simulations experimentally, the parameters leaching medium, $\mathrm{pH}$-additive, and further components have an influence on the precipitate phase and thus on the $\mathrm{pH}$-value of precipitation. Experimental validation by titration is a suitable tool to validate the calculations. Titration is therefore going to be performed in the frame of this publication's Part II. The literature-based information gives an insight on the degree of dissolution, and besides, on the precipitation behavior. Thus, it is complementary to the simulation data. However, the data presented are also specific studies and might not be transferrable to any system. The data derived from literature provide a first orientation to forecast the hydrometallurgical behavior and thus construct a suitable recycling path. Experimental validation within Part II is going to evaluate the approaches presented in this study.

Figure 5 shows a thermochemical modelling by StabCal in terms of the behavior of the element $\mathrm{Zr}$ when being brought into aqueous solution. It can be seen that the $\mathrm{Zr}$-ions are starting to precipitate from the leaching liquor at a $\mathrm{pH}$-value of $\sim 4.5$ as $\mathrm{ZrO}_{2}$. 


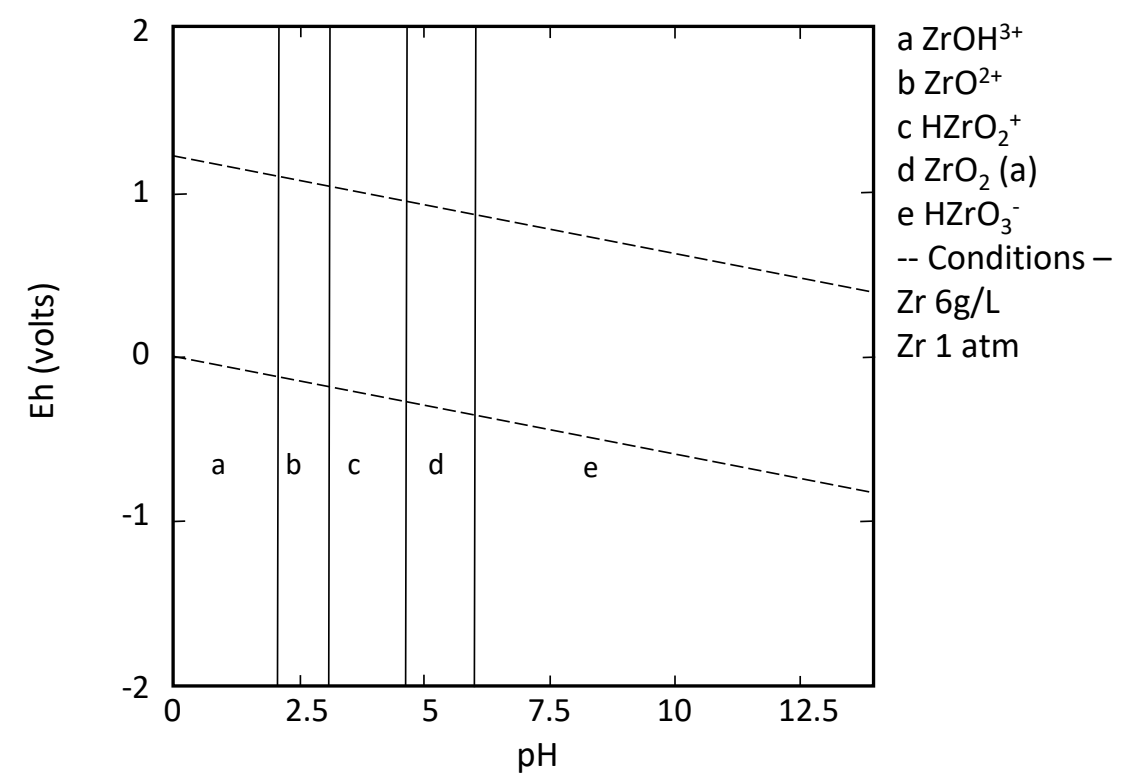

Figure 5. EpH diagram of $\mathrm{Zr}$ dependent of $\mathrm{pH}$ calculated by StabCal. Database used: Helgeson (SupCrt).

In the literature, this phenomenon has been discussed, as well: Ma et al. built a phase diagram and calculated a precipitation of $\mathrm{ZrO}_{2}$ from the leaching liquor at a $\mathrm{pH}$-value of 2.5 (see Figure 6) [70]. The results show slight deviations but general accordance with the StabCal simulation in Figure 5, especially taking into account the high degree of simplification discussed above. Moreover, Ma et al. treated an eudialyte concentrate in $\mathrm{H}_{2} \mathrm{SO}_{4}$, and adjusted the $\mathrm{pH}$-value by sodium carbonate $\left(\mathrm{Na}_{2} \mathrm{CO}_{3}\right)$. Thus, deviations by further components in the system are likely to occur.

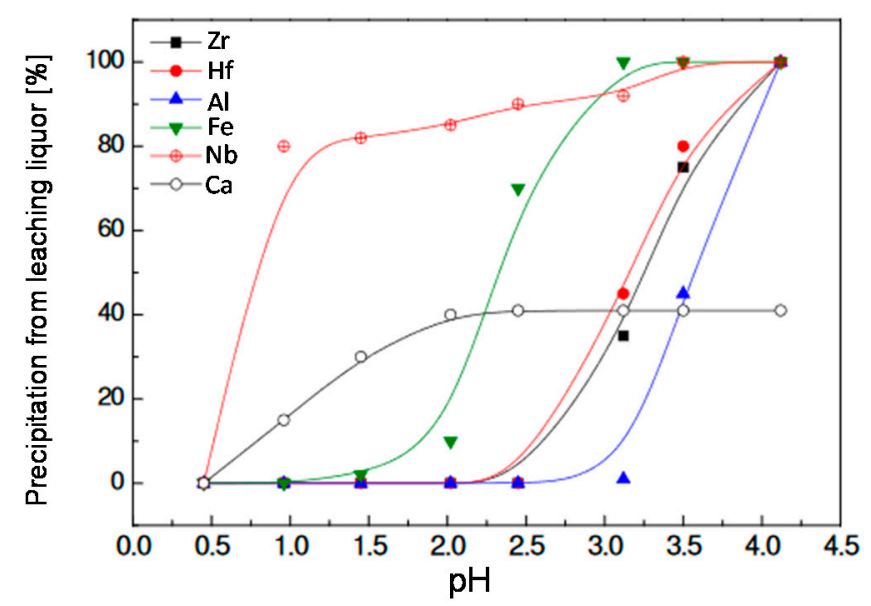

Figure 6. Influence of $\mathrm{pH}$-value in terms of precipitation of $\mathrm{Zr}$ stemming from eudialyte from a $\mathrm{H}_{2} \mathrm{SO}_{4}$ solution, based on [70].

In general, $\mathrm{ZrO}_{2}$ can be leached in an acidic medium, as reported by Ferreira et al. in case of nitric acid $\left(\mathrm{HNO}_{3}\right)$. They have shown a $\mathrm{Zr}$ dissolution of $95 \%$ with a leaching time of $4 \mathrm{~h}$, an operating temperature of $70^{\circ} \mathrm{C}$, and a molality of $12.0 \mathrm{~mol} / \mathrm{L}$ [71].

Figure 7 shows a thermochemical modelling by StabCal in terms of the behavior of the element La when being brought into aqueous solution. From this calculation, a precipitation of La-ions in a $\mathrm{pH}$-area of $\sim 7.4$ is predicted. 


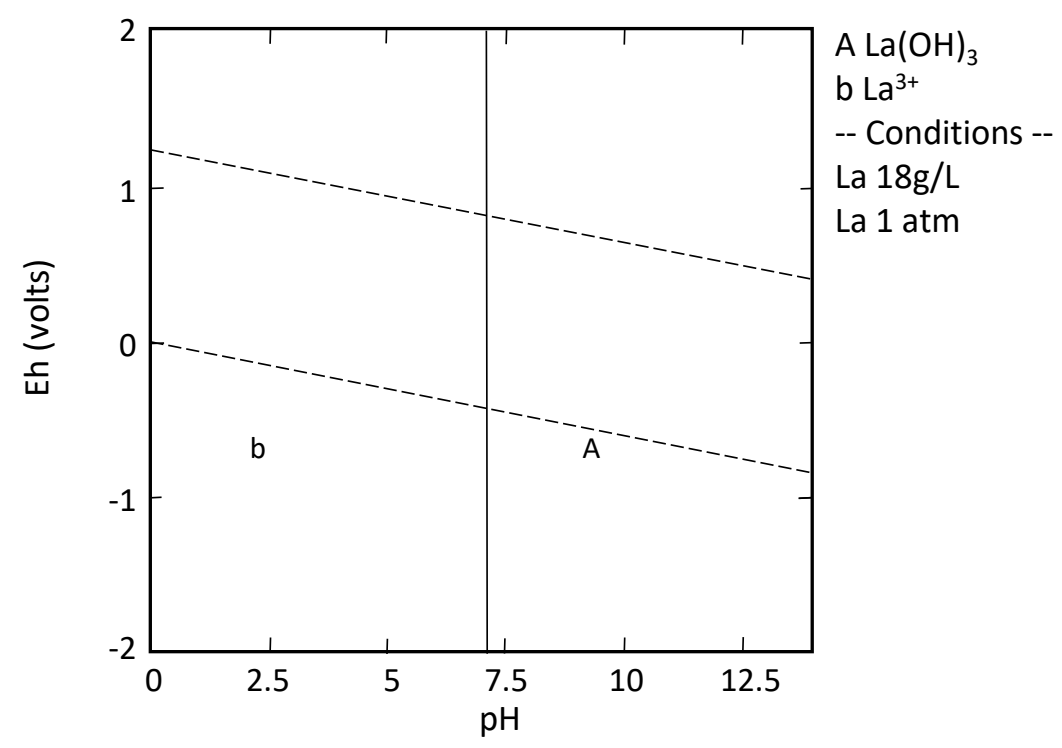

Figure 7. EpH diagram of La dependent on $\mathrm{pH}$ calculated by StabCal. Database used: LLNL (Cp(T)).

Literature on the dissolution of La-phases has shown a good accordance with the StabCal simulation presented. Orhanovic et al. reported a precipitation $\mathrm{pH}$-value of 7.36-7.56 for $\mathrm{La}(\mathrm{OH})_{3}$ [72]. Um et al. examined the dissolution of $\mathrm{La}_{2} \mathrm{O}_{3}$ in $\mathrm{H}_{2} \mathrm{SO}_{4}$, leading to a full leachability, see Figure 8 [73].

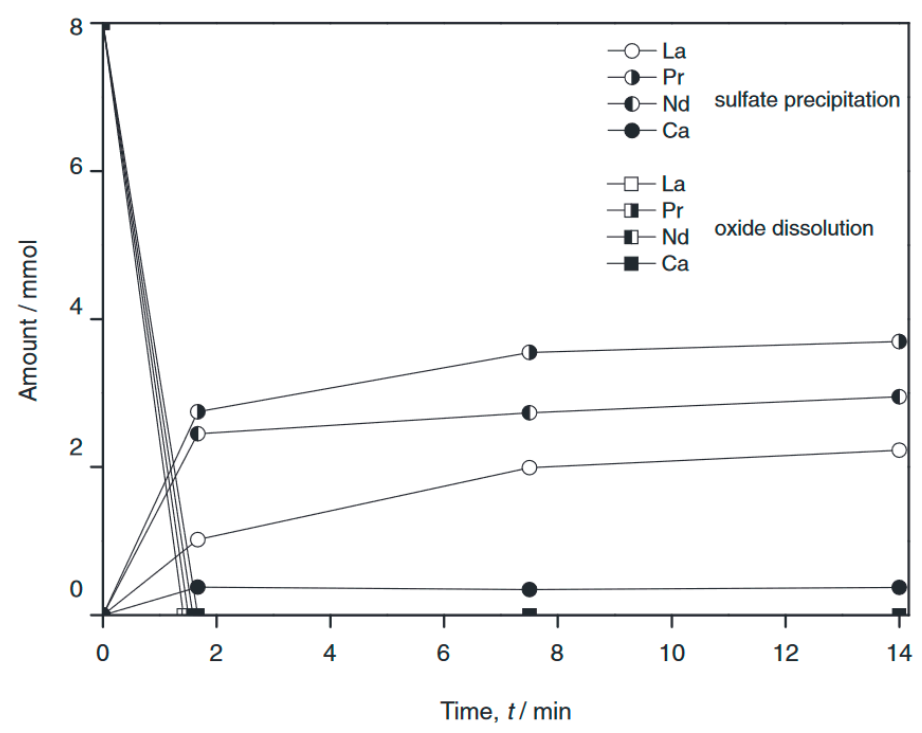

Figure 8. $\mathrm{La}_{2} \mathrm{O}_{3}$ dissolution and conversion into $\mathrm{La}_{2}\left(\mathrm{SO}_{4}\right)[73]$.

Figure 9 shows thermochemical modelling by StabCal in terms of the behavior of the element Ta when being brought into the aqueous solution. From the simulation, no $\mathrm{pH}$-dependent precipitation threshold can be identified.

However, a literature research gives more information on the dissolution and precipitation of Ta-compounds dependent on the $\mathrm{pH}$-value. Chen et al. report a low Ta leaching efficiencies in $\mathrm{HCl}$, $\mathrm{H}_{2} \mathrm{SO}_{4}$ and $\mathrm{HNO}_{3}$ [74]. When applying hydrogen fluoride (HF) based pressure leaching, at 23 bar, $180{ }^{\circ} \mathrm{C}$ for $3 \mathrm{~h}$, a leaching efficiency of $99 \%$ could be obtained [74]. Regarding Ta-recovery from the solution by solvent extraction, an extraction efficiency of $99.5 \%$ could be reached at $\mathrm{pH}=1$ (see Figure 10). Nevertheless, solvent extraction can extract ions selectively dependent on the solvent applied, and thus, the system behaviour cannot be transferred linearly to acidification/basification-driven precipitation 
(conventional hydrometallurgy by $\mathrm{pH}$-adjustment). Hence, the extraction efficiency describes the dissolution within the solvent; research on basification-driven precipitation will be presented below.

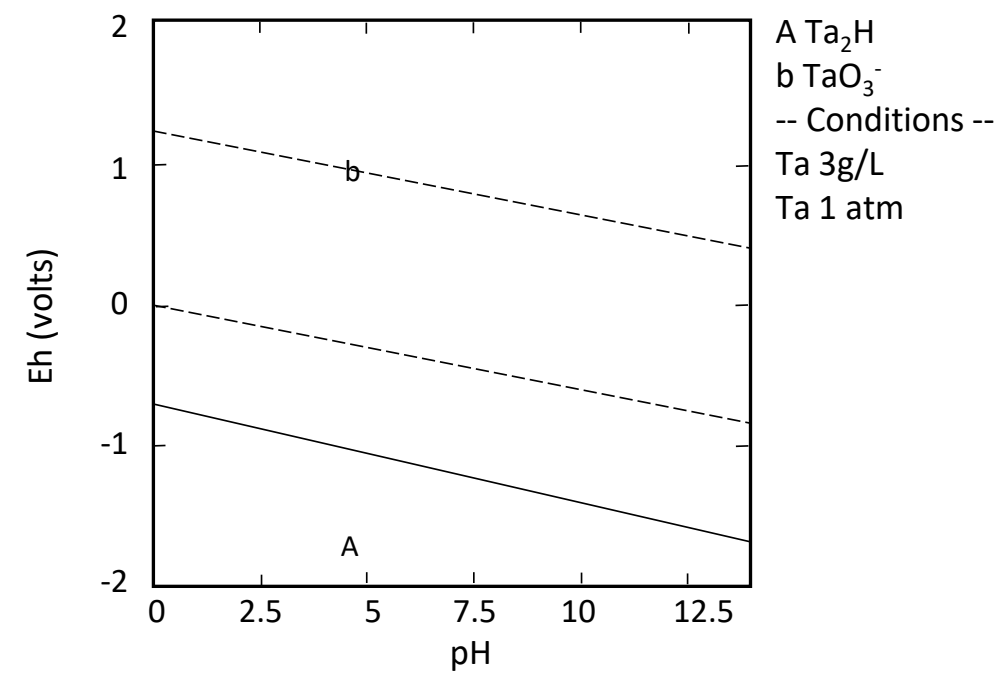

Figure 9. EpH diagram of Ta dependent of $\mathrm{pH}$ calculated by StabCal. Database used: HSC (Outotch).

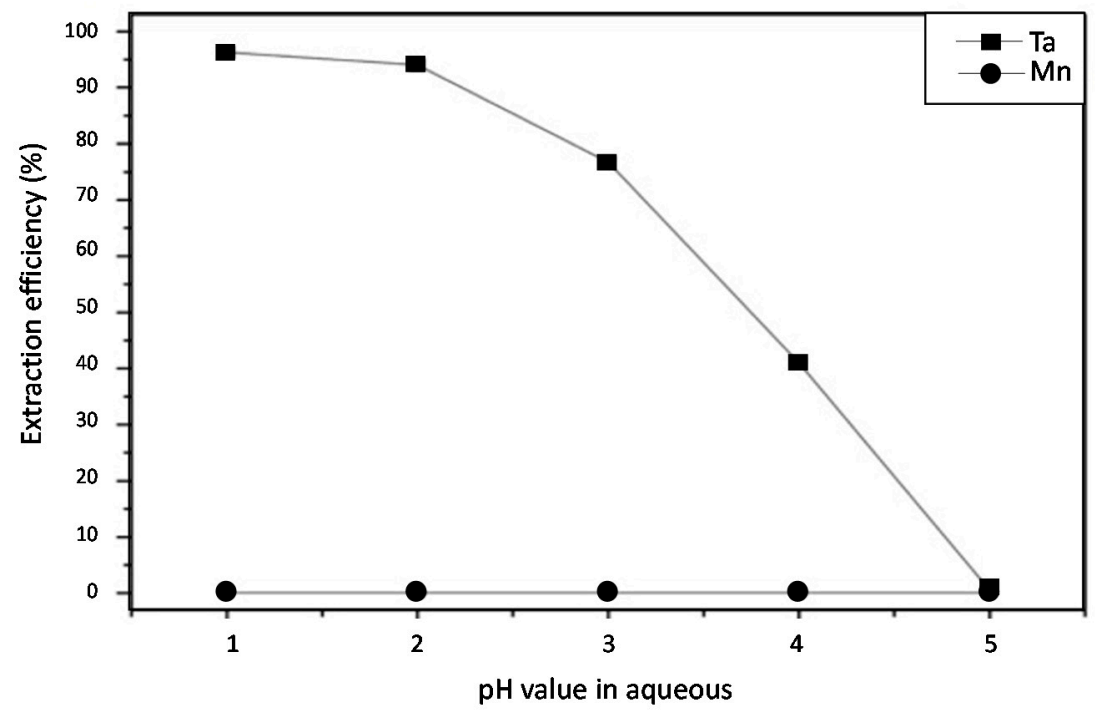

Figure 10. Influence of $\mathrm{pH}$-value 1-5 on the extraction efficiency of Ta using Alamine 336 for solvent extraction, based on [74].

Clark and Brown confirm the dissolution behaviour detected by Chen et al. stating the capability of Ta to dissolve in alkaline solutions [75]. This is also supported by Deblonde et al. [76,77]. Here, alkaline leaching in sodium hydroxide $(\mathrm{NaOH})$ or potassium hydroxide $(\mathrm{KOH})$ shows a good hydrometallurgical alternative to fluorine-based leaching, which is critical in terms of toxic emissions [77]. Deblonde et al. report on a combination process consisting of alkaline leaching and $\mathrm{pH}$-value adjustment to $\mathrm{pH}=2-7$ in order to precipitate Ta [77]. Thus, it can be concluded that Ta is likely to precipitate in an acidic area and might cause contaminations in the $\mathrm{Cu}$-cementation step or the Al-Fe-hydroxide precipitation according to Wang [18]. The same option is valid for $\mathrm{La}$ and $\mathrm{Zr}$, which tend to precipitate in acidic areas, too, as described above. When assuming a highly selective hydrometallurgical treatment, a precipitation into element-specific product will be realizable though.

The simulated properties were, hence, combined with a literature research in order to extract a recycling process in terms of multi-step hydrometallurgy. The process design of a multi-step 
hydrometallurgy can be applied to the two scenarios shown in Table 3. In combination with the behavior of the elements in the active mass, $\mathrm{Zr}, \mathrm{La}$, and $\mathrm{Ta}$, and the conventional NMC-chemistry, one flow-chart for scenario 1 and one flow-chart for scenario 2 regarding a multi-step hydrometallurgy are presented in Figures 11 and 12. Since the oxidation states of the input material cannot be forecasted, neither the phase of the precipitates is specified in this elaboration.

\section{Scenario 1}

As already suggested in Table 3, scenario 1 represents the case of bringing all battery components into solution. Since LLZ implies garnets, an aggressive leaching medium has to be chosen here. Then, the specific elements can be precipitated according to an increased pH-value e.g., as hydroxides, sulfates, or oxides. Since the precipitation of metals can be estimated according to the elaborations from Figures 5-10, the following multi-step hydrometallurgy is suggested for scenario 1.

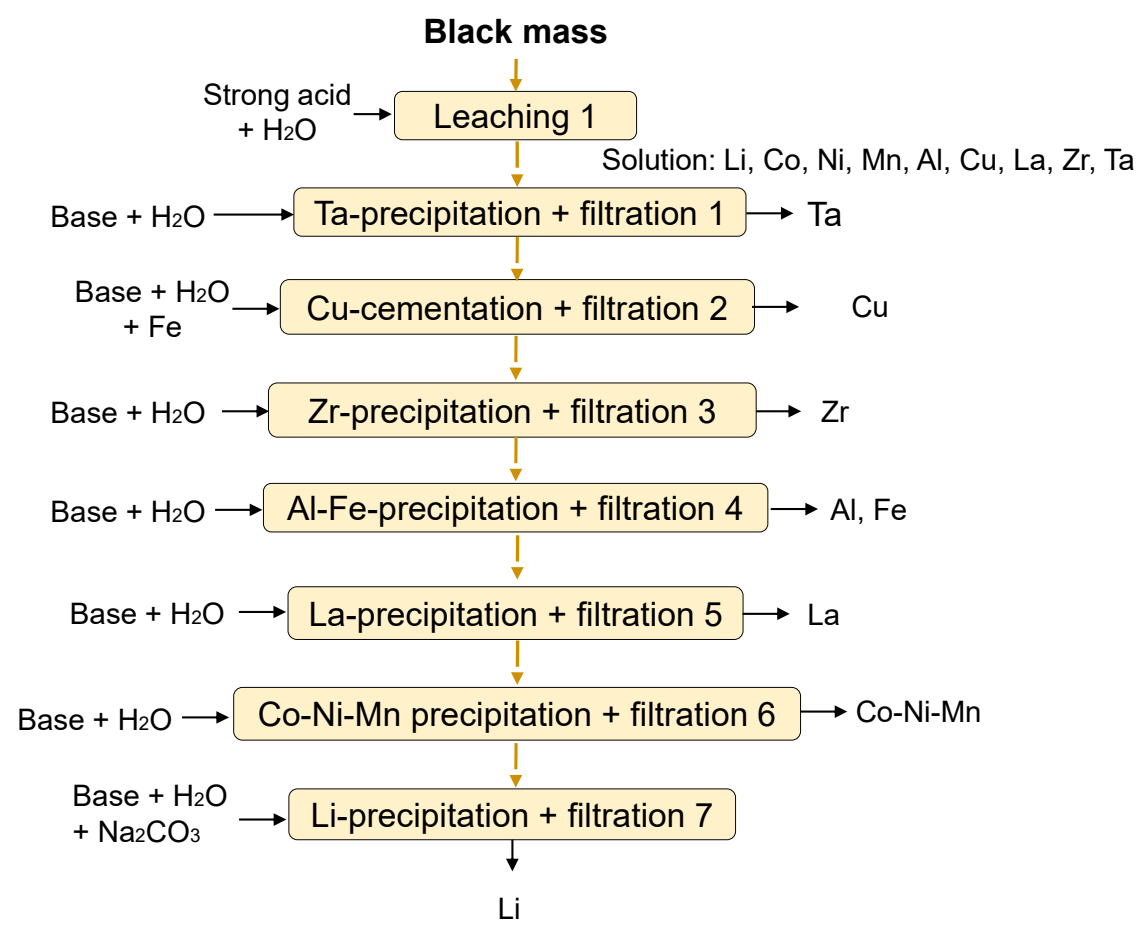

Figure 11. Developed recycling path for multi-step hydrometallurgy (Scenario 1: Full dissolution of garnet structure $\rightarrow$ aggressive leaching).

\section{Scenario 2}

In the case of moderate leaching, the garnet structure is not dissolved. However, depending on the acid chosen, the presented system behavior of scenario 2 can also occur although an aggressive leaching medium is chosen. In contrast, a milling step, as indicated in Figure 4 by the term "Crushing", could also enhance $\mathrm{Li}$ liberation. The $\mathrm{Li}^{+} / \mathrm{H}^{+}$exchange is also realizable in aqueous or moderate leaching. Hence, a combination of milling and moderate leaching is to be experimentally evaluated in terms of leaching behaviour according to scenario 1. As described above, Ta would not be brought into solution, even if choosing a strong acid, except of HF. If La is not diluted, which can be the case for an unsuitable leaching medium as well, it will be filtered along with Ta. Subsequently, alkaline leaching could dissolve Ta and thus, enable a separation between La and Ta. Hence, all the garnet oxides can be selectively separated also by scenario 2 .

Thus, the focal point of the experimental investigations will be a determination of suitable pre-treatments, both mechanically and thermally. Furthermore, the extractive hydrometallurgy aiming for a zero-waste and maximum yield, especially based on $\mathrm{Co}$ and $\mathrm{Ni}$, is to be developed. 


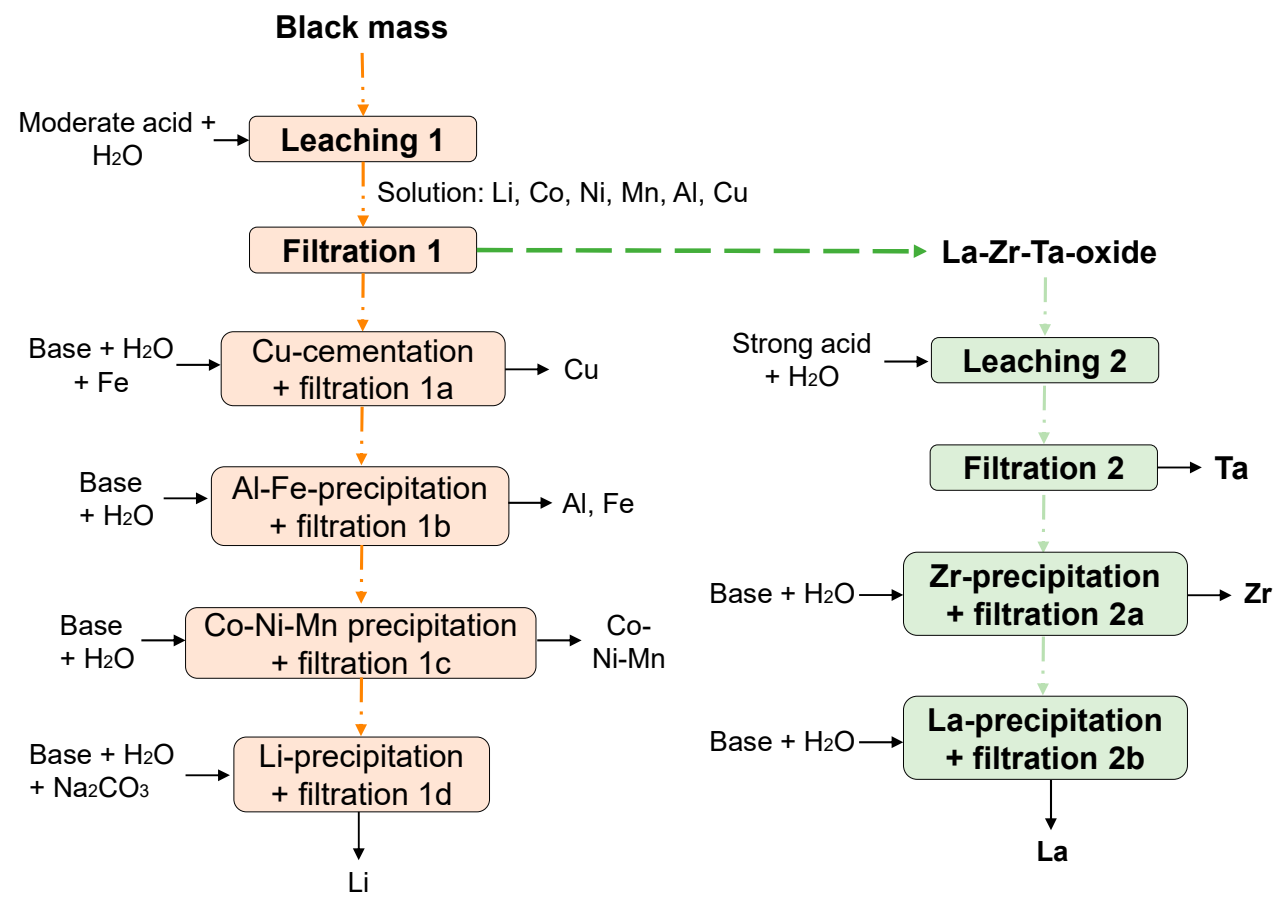

Figure 12. Developed recycling path for multi-step hydrometallurgy (Scenario 2: No dissolution of garnet structure $\rightarrow$ moderate leaching).

\section{Conclusions}

A technology's recyclability at its prototype development stage is a progressive and, according to the authors opinion, crucial approach for contributing to a both high-tech and highly sustainable world. Investigating a technology's recyclability at this stage generates an understanding of its future viability and, moreover, drawing up recommendations in terms of a "design for recycling". In this way, performance and sustainability are brought together, leading to the best technology concept in both economic and ecological value.

This study is the first attempt in approaching suitable recycling paths for oxide-based ASBs. Different options have been pointed out, focusing either on conventional LIB treatment steps or on innovative methods for a specifically tailored process.

According to our evaluation, the most promising pre-process is shown in Figure 4, and in combination with a detailed multi-step hydrometallurgy steps in Figure 12 leads to an optimal recycling yield. The dissolution of the garnet structure could require strong acids, which can lead to undesired environmental impacts and thus, should be avoided. Moreover, less cross-contaminations with conventional NMC-components and thus a higher recycling efficiency can be expected. If a thermal treatment is required, it should be tested experimentally, and if an ESLR is implied (see Figure 4), the final step regarding the Li carbonate recovery in Figure 12 can be foregone. However, in contrast to environmental and recycling efficiency considerations, the economic perspective is not taken into account here.

\section{Outlook}

Future research will focus on experimental implementation of the theoretical concepts drawn up within this study. Thus, mass balances and chemical analysis will examine the validity of the theoretical concept and thereby contribute to sustainability assessments of next-generation batteries. This research will be shown in "Recycling Concept for Ceramic All-Solid-State Batteries-Part II: Experimental validation for a LLZ + NMC-based System". 
Author Contributions: Conceptualization, L.S. and M.K.; methodology, L.S., M.K., and A.S.; software, L.S.; validation, L.S., M.K., A.S., M.F., and B.F.; investigation, L.S., M.K., A.S., and M.F.; resources, L.S., M.K., A.S., and M.F.; data curation, L.S., M.K., A.S., and M.F.; writing-original draft preparation, L.S., M.K., A.S., and M.F.; writing-review and editing, L.S. and M.F.; visualization, L.S., M.K., and A.S.; supervision, M.F., D.F.-R., O.G., and B.F.; project administration, M.F.; funding acquisition, M.F., D.F.-R., and O.G. All authors have read and agreed to the published version of the manuscript.

Funding: This research was funded by the Helmholtz Association and the German Federal Ministry of Education and Research (BMBF) in the framework of the project "FestBatt-Oxide" (FKZ: 13XP0173A).

Conflicts of Interest: The authors declare no conflict of interest.

\section{References}

1. Olivetti, E.A.; Ceder, G.; Gaustad, G.G.; Fu, X. Lithium-ion battery supply chain considerations: Analysis of potential bottlenecks in critical metals. Joule 2017, 1, 229-243. [CrossRef]

2. Harper, G.; Sommerville, R.; Kendrick, E.; Driscoll, L.; Slater, P.; Stolkin, R.; Walton, A.; Christensen, P.; Heidrich, O.; Lambert, S.; et al. Recycling lithium-ion batteries from electric vehicles. Nature 2019, 575, 75-86. [CrossRef] [PubMed]

3. Zheng, X.; Zhu, Z.; Lin, X.; Zhang, Y.; He, Y.; Cao, H.; Sun, Z. A Mini-Review on Metal Recycling from Spent Lithium Ion Batteries. Engineering 2018, 4, 361-370. [CrossRef]

4. Zhao, S.; He, W.; Li, G. Recycling Technology and Principle of Spent Lithium-Ion Battery. In Recycling of Spent Lithium-Ion Batteries; An, L., Ed.; Springer International Publishing: Cham, Switzerland, 2019; pp. 1-26.

5. Träger, T.; Friedrich, B.; Weyhe, R. Recovery Concept of Value Metals from Automotive Lithium-Ion Batteries. Chem. Ing. Tech. 2015, 87, 1550-1557. [CrossRef]

6. Diaz, F.; Wang, Y.; Moorthy, T.; Friedrich, B. Degradation Mechanism of Nickel-Cobalt-Aluminum (NCA) Cathode Material from Spent Lithium-Ion Batteries in Microwave-Assisted Pyrolysis. Metals 2018, 8, 565. [CrossRef]

7. Ekberg, C.; Petranikova, M. Lithium Batteries Recycling. In Lithium Process Chemistry. Resources, Extraction, Batteries, and Recycling; Chagnes, A., Światowska, J., Eds.; Elsevier: Amsterdam, The Netherlands, 2015; pp. 233-267.

8. Wang, H.; Vest, M.; Friedrich, B. Hydrometallurgical processing of Li-Ion battery scrap from electric vehicles. In Proceedings of the EMC 2011, Düsseldorf, Germany, 26-29 June 2011; Harre, J., Ed.; GDMB: Clausthal-Zellerfeld, Germany, 2011.

9. Lombardo, G.; Ebin, B.; Foreman, M.R.S.J.; Steenari, B.-M.; Petranikova, M. Chemical Transformations in Li-Ion Battery Electrode Materials by Carbothermic Reduction. ACS Sustain. Chem. Eng. 2019, 7, 13668-13679. [CrossRef]

10. Zhang, G.; Du, Z.; He, Y.; Wang, H.; Xie, W.; Zhang, T. A Sustainable Process for the Recovery of Anode and Cathode Materials Derived from Spent Lithium-Ion Batteries. Sustainability 2019, 11, 2363. [CrossRef]

11. Meshram, P.; Pandey, B.D.; Mankhand, T.R. Recovery of valuable metals from cathodic active material of spent lithium ion batteries: Leaching and kinetic aspects. Waste Manag. 2015, 45, 306-313. [CrossRef]

12. Sun, L.; Qiu, K. Vacuum pyrolysis and hydrometallurgical process for the recovery of valuable metals from spent lithium-ion batteries. J. Hazard. Mater. 2011, 194, 378-384. [CrossRef]

13. Hanisch, C.; Loellhoeffel, T.; Diekmann, J.; Markley, K.J.; Haselrieder, W.; Kwade, A. Recycling of lithium-ion batteries: A novel method to separate coating and foil of electrodes. J. Clean. Prod. 2015, 108, 301-311. [CrossRef]

14. Or, T.; Gourley, S.W.D.; Kaliyappan, K.; Yu, A.; Chen, Z. Recycling of mixed cathode lithium-ion batteries for electric vehicles: Current status and future outlook. Carbon Energy 2020, 2, 6-43. [CrossRef]

15. Pagliaro, M.; Meneguzzo, F. Lithium battery reusing and recycling: A circular economy insight. Heliyon 2019, 5, e01866. [CrossRef] [PubMed]

16. Zheng, Y.; Song, W.; Mo, W.-T.; Zhou, L.; Liu, J.-W. Lithium fluoride recovery from cathode material of spent lithium-ion battery. RSC Adv. 2018, 8, 8990-8998. [CrossRef]

17. Chen, Y.; Liu, N.; Jie, Y.; Hu, F.; Li, Y.; Wilson, B.P.; Xi, Y.; Lai, Y.; Yang, S. Toxicity Identification and Evolution Mechanism of Thermolysis-Driven Gas Emissions from Cathodes of Spent Lithium-Ion Batteries. ACS Sustain. Chem. Eng. 2019, 7, 18228-18235. [CrossRef] 
18. Wang, H.; Friedrich, B. Development of a Highly Efficient Hydrometallurgical Recycling Process for Automotive Li-Ion Batteries. J. Sustain. Metall. 2015, 1, 168-178. [CrossRef]

19. Yin, H.; Xing, P. Pyrometallurgical Routes Pyrometallurgical Routes for the Recycling of Spent Lithium-Ion Batteries. In Recycling of Spent Lithium-Ion Batteries; An, L., Ed.; Springer International Publishing: Cham, Switzerland, 2019; pp. 57-83.

20. Pinegar, H.; Smith, Y.R. Recycling of End-of-Life Lithium Ion Batteries, Part I: Commercial Processes. J. Sustain. Metall. 2019, 5, 402-416. [CrossRef]

21. Georgi-Maschler, T.; Friedrich, B.; Weyhe, R.; Heegn, H.; Rutz, M. Development of a recycling process for Li-ion batteries. J. Power Sources 2012, 207, 173-182. [CrossRef]

22. Heelan, J.; Gratz, E.; Zheng, Z.; Wang, Q.; Chen, M.; Apelian, D.; Wang, Y. Current and Prospective Li-Ion Battery Recycling and Recovery Processes. JOM 2016, 68, 2632-2638. [CrossRef]

23. Chagnes, A.; Pospiech, B. A brief review on hydrometallurgical technologies for recycling spent lithium-ion batteries. J. Chem. Technol. Biotechnol. 2013, 88, 1191-1199. [CrossRef]

24. Swain, B. Recovery and recycling of lithium: A review. Sep. Purif. Technol. 2017, 172, 388-403. [CrossRef]

25. Kwade, A. Project Website InnoRec. 2019. Available online: https://www.prozell-cluster.de/en/projects/ innorec/ (accessed on 24 March 2020).

26. VDI/VDE Innovation + Technik GmbH. Project Website Mercator. 2019. Available online: https://www. erneuerbar-mobil.de/en/node/1232 (accessed on 16 November 2020).

27. Stallmeister, C.; Schwich, L.; Friedrich, B. Early-Stage Li-Removal -Vermeidung von Lithiumverlusten im Zuge der Thermischen und Chemischen Recyclingrouten von Batterien. In Recycling und Sekundärrohstoffe, Band 13; Thomé-Kozmiensky, E., Holm, O., Friedrich, B., Goldmann, D., Eds.; Thomé-Kozmiensky Verlag GmbH: Neuruppin, Germany, 2020; pp. 545-557.

28. Hu, J.; Zhang, J.; Li, H.; Chen, Y.; Wang, C. A promising approach for the recovery of high value-added metals from spent lithium-ion batteries. J. Power Sources 2017, 351, 192-199. [CrossRef]

29. Li, J.; Wang, G.; Xu, Z. Environmentally-friendly oxygen-free roasting/wet magnetic separation technology for in situ recycling cobalt, lithium carbonate and graphite from spent $\mathrm{LiCoO}_{2} /$ graphite lithium batteries. J. Hazard. Mater. 2016, 302, 97-104. [CrossRef] [PubMed]

30. Bertau, M.; Martin, G. Integrated Direct Carbonation Process for Lithium Recovery from Primary and Secondary Resources. MSF 2019, 959, 69-73. [CrossRef]

31. Vanderbruggen, A.; Rudolph, M. Flotation of Spherodized Graphite from Spent Lithium Ion Batteries. 2020. Available online: https://www.researchgate.net/publication/338630299_Recovery_of_spheroidized_graphite_ from_spent_lithium_ion_batteries_Talk_at_AABC_Europe (accessed on 16 November 2020).

32. He, Y.; Zhang, T.; Wang, F.; Zhang, G.; Zhang, W.; Wang, J. Recovery of $\mathrm{LiCoO}_{2}$ and graphite from spent lithium-ion batteries by Fenton reagent-assisted flotation. J. Clean. Prod. 2017, 143, 319-325. [CrossRef]

33. Paulino, J.F.; Busnardo, N.G.; Afonso, J.C. Recovery of valuable elements from spent Li-batteries. J. Hazard. Mater. 2008, 150, 843-849. [CrossRef]

34. Hosseini-Bab-Anari, E.; Boschin, A.; Mandai, T.; Masu, H.; Moth-Poulsen, K.; Johansson, P. Fluorine-free salts for aqueous lithium-ion and sodium-ion battery electrolytes. RSC Adv. 2016, 6, 85194-85201. [CrossRef]

35. Davenport, W.G. Extractive Metallurgy of Nickel, Cobalt, and Platinum Group Materials; Elsevier: Amsterdam, The Netherlands, 2011.

36. Pinegar, H.; Smith, Y.R. Recycling of End-of-Life Lithium-Ion Batteries, Part II: Laboratory-Scale Research Developments in Mechanical, Thermal, and Leaching Treatments. J. Sustain. Metall. 2020, 6, 142-160. [CrossRef]

37. Janek, J.; Zeier, W.G. A solid future for battery development. Nat. Energy 2016, 1, 1167. [CrossRef]

38. Kurzweil, P.; Dietlmeier, O.K. Elektrochemische Speicher: Superkondensatoren, Batterien, Elektrolyse-Wasserstoff, Rechtliche Grundlagen, 1. Aufl.; Springer Fachmedien Wiesbaden: Wiesbaden, Germany, 2015.

39. Tsai, C.-L.; Ma, Q.; Dellen, C.; Lobe, S.; Vondahlen, F.; Windmüller, A.; Grüner, D.; Zheng, H.; Uhlenbruck, S.; Finsterbusch, M.; et al. A garnet structure-based all-solid-state Li battery without interface modification: Resolving incompatibility issues on positive electrodes. Sustain. Energy Fuels 2019, 3, 280-291. [CrossRef]

40. Troy, S.; Schreiber, A.; Reppert, T.; Gehrke, H.-G.; Finsterbusch, M.; Uhlenbruck, S.; Stenzel, P. Life Cycle Assessment and resource analysis of all-solid-state batteries. Appl. Energy 2016, 169, 757-767. [CrossRef]

41. Erdmann, L.; Graedel, T.E. Criticality of non-fuel minerals: A review of major approaches and analyses. Environ. Sci. Technol. 2011, 45, 7620-7630. [CrossRef] [PubMed] 
42. Graedel, T.E.; Barr, R.; Chandler, C.; Chase, T.; Choi, J.; Christoffersen, L.; Friedlander, E.; Henly, C.; Jun, C.; Nassar, N.T.; et al. Methodology of metal criticality determination. Environ. Sci. Technol. 2012, 46, 1063-1070. [CrossRef]

43. Ambrose, H.; Kendall, A. Understanding the future of lithium: Part 1, resource model. J. Ind. Ecol. 2020, 24, 80-89. [CrossRef]

44. Simon, B.; Ziemann, S.; Weil, M. Criticality of metals for electrochemical energy storage systems-Development towards a technology specific indicator. Metall. Res. Technol. 2015, 111, 191-200. [CrossRef]

45. Helbig, C.; Bradshaw, A.M.; Wietschel, L.; Thorenz, A.; Tuma, A. Supply risks associated with lithium-ion battery materials. J. Clean. Prod. 2018, 172, 274-286. [CrossRef]

46. Buchholz, P.; Huy, D.; Sievers, H. DERA-Rohstoffliste 2012, Angebotskonzentration bei Metallen und Industriemineralien-Potenzielle Preis-und Lieferrisiken; Deutsche Rohstoffagentur (DERA) in der Bundesanstalt für Geowissenschaften und Rohstoffe: Berlin, Germany, 2012; Volume 10.

47. LITHOREC. Recycling von Lithium-Ionen-Batterien-LithoRec II. Abschlussberichte der Beteiligten Verbundpartner. 2012. Available online: https:/www.erneuerbar-mobil.de/sites/default/files/2017-01/ Abschlussbericht_LithoRec_II_20170116.pdf (accessed on 1 October 2020).

48. Deloitte Sustainability; British Geological Survey; Bureau de Recherches Géologiques et Minières; Netherlands Organisation for Applied Scientific Research. Study on the Review of the List of Critical Raw Materials. Criticality Assessments. 2017. Available online: https://op.europa.eu/en/publication-detail/-/publication/ 08fdab5f-9766-11e7-b92d-01aa75ed71a1/language-en (accessed on 16 November 2020).

49. Joint Research Centre. The European Commission's In-House Science Service: Annual Report 2013; Report EUR 26372 EN; Publications Office of the European Union: Luxembourg, 2014.

50. Schultz, D.; Kuckshinrichs, W. The need for lithium-An upcoming problem of electrochemical energy storages? J. Energy Chall. Mech. 2016, 3, 180-185.

51. Piana, G.; Ricciardi, M.; Bella, F.; Cucciniello, R.; Proto, A.; Gerbaldi, C. Poly(glycidyl ether)s recycling from industrial waste and feasibility study of reuse as electrolytes in sodium-based batteries. Chem. Eng. J. 2020, 382, 122934. [CrossRef]

52. Wang, Y.-Y.; Diao, W.-Y.; Fan, C.-Y.; Wu, X.-L.; Zhang, J.-P. Benign Recycling of Spent Batteries towards All-Solid-State Lithium Batteries. Chemistry 2019, 25, 8975-8981. [CrossRef]

53. Tsai, C.-L.; Roddatis, V.; Chandran, C.V.; Ma, Q.; Uhlenbruck, S.; Bram, M.; Heitjans, P.; Guillon, O. Li7La3Zr2O12 Interface Modification for Li Dendrite Prevention. ACS Appl. Mater. Interfaces 2016, 8, 10617-10626. [CrossRef]

54. Uhlenbruck, S.; Dornseiffer, J.; Lobe, S.; Dellen, C.; Tsai, C.-L.; Gotzen, B.; Sebold, D.; Finsterbusch, M.; Guillon, O. Cathode-electrolyte material interactions during manufacturing of inorganic solid-state lithium batteries. J. Electroceram. 2017, 38, 197-206. [CrossRef]

55. Park, K.; Yu, B.-C.; Jung, J.-W.; Li, Y.; Zhou, W.; Gao, H.; Son, S.; Goodenough, J.B. Electrochemical Nature of the Cathode Interface for a Solid-State Lithium-Ion Battery: Interface between $\mathrm{LiCoO}_{2}$ and Garnet-Li $\mathrm{La}_{3} \mathrm{Zr}_{2} \mathrm{O}_{12}$. Chem. Mater. 2016, 28, 8051-8059. [CrossRef]

56. Ren, Y.; Liu, T.; Shen, Y.; Lin, Y.; Nan, C.-W. Chemical compatibility between garnet-like solid state electrolyte Li6.75La3Zr1.75Ta0.25O12 and major commercial lithium battery cathode materials. J. Mater. 2016, 2, 256-264. [CrossRef]

57. DeWees, R.; Wang, H. Synthesis and Properties of NaSICON-type LATP and LAGP Solid Electrolytes. ChemSusChem 2019, 12, 3713-3725. [CrossRef] [PubMed]

58. Kato, T.; Iwasaki, S.; Ishii, Y.; Motoyama, M.; West, W.C.; Yamamoto, Y.; Iriyama, Y. Preparation of thick-film electrode-solid electrolyte composites on $\mathrm{Li}_{7} \mathrm{La}_{3} \mathrm{Zr}_{2} \mathrm{O}_{12}$ and their electrochemical properties. J. Power Sources 2016, 303, 65-72. [CrossRef]

59. Thielmann, A.; Neef, C.; Hettesheimer, T.; Döscher, H.; Wietschel, M.; Tübke, J. Energiespeicher-Roadmap. 2017. Available online: https://www.isi.fraunhofer.de/content/dam/isi/dokumente/cct/lib/EnergiespeicherRoadmap-Dezember-2017.pdf (accessed on 23 March 2020).

60. United States Geological Survey. U.S. Geological Survey: Mineral Commodity Summaries; United States Geological Survey: Reston, VA, USA, 2020.

61. Reichl, C.; Schatz, M.; Zsak, G. World-Mining-Data Welt-Bergbau-Daten. 2014. Available online: https: //www.univie.ac.at/Mineralogie/docs/Weltbergbaudaten_2014.pdf (accessed on 1 October 2020). 
62. Brown, T.J.; Idoine, N.E.; Wrighton, C.E.; Raycraft, E.R.; Hobbs, S.F.; Shaw, R.A.; Everett, P.; Kresse, C.; Deady, E.A.; Bide, T. World Mineral Production 2014-2018; British Geological Survey: Nottingham, UK, 2019.

63. Available online: https://www.statista.com/statistics/280060/share-of-global-rare-earth-supply-by-element2015/ (accessed on 1 October 2020).

64. Peters, L.; Schier, C.; Friedrich, B. Lithium- und Kobalt-Rückgewinnung aus Elektrolichtbogenofenschlacken des Batterie-Recyclings. In Mineralische Nebenprodukte und Abfälle. Aschen, Schlacken, Stäube und Baurestmassen; Thiel, S., Thomé-Kozmiensky, E., Friedrich, B., Pretz, T., Quicker, P., Senk, D., Wotruba, H., Eds.; Thomé-Kozmiensky Verlag GmbH: Neuruppien, Germany, 2018; pp. 338-359.

65. Wang, H.; Friedmann, D.; Vest, M.; Friedrich, B. Innovative Recycling of Li-Based Electric Vehicle Batteries, General Hydrometallurgy, General Pyrometallurgy/Vessel Integrity/Process Gas Treatment, Recycling. Posters, Authors Index, Keywords Index; GDMB Verlag: Clausthal-Zellerfeld, Germany, 2013.

66. Lide, D.R. (Ed.) A ready-reference book of chemical and physical data. In CRC Handbook of Chemistry and Physics; CRC Press: Boca Raton, FL, USA, 2003.

67. Larraz, G.; Orera, A.; Sanjuán, M.L. Cubic phases of garnet-type Li7La3Zr2O12: The role of hydration. J. Mater. Chem. A 2013, 1, 11419. [CrossRef]

68. Liu, X.; Chen, Y.; Hood, Z.D.; Ma, C.; Yu, S.; Sharafi, A.; Wang, H.; An, K.; Sakamoto, J.; Siegel, D.J.; et al. Elucidating the mobility of $\mathrm{H}+$ and $\mathrm{Li}+$ ions in ( $\mathrm{Li} 6.25-x \mathrm{HxAl0} .25) \mathrm{La} 3 \mathrm{Zr} 2 \mathrm{O} 12$ via correlative neutron and electron spectroscopy. Energy Environ. Sci. 2019, 12, 945-951. [CrossRef]

69. Ma, C.; Rangasamy, E.; Liang, C.; Sakamoto, J.; More, K.L.; Chi, M. Excellent stability of a lithium-ion-conducting solid electrolyte upon reversible $\mathrm{Li}(+) / \mathrm{H}(+)$ exchange in aqueous solutions. Angew. Chem. Int. Ed. Engl. 2015, 54, 129-133. [CrossRef]

70. Ma, Y.; Stopic, S.; Wang, X.; Forsberg, K.; Friedrich, B. Basic Sulfate Precipitation of Zirconium from Sulfuric Acid Leach Solution. Metals 2020, 10, 1099. [CrossRef]

71. Ferreira, C.A.; Formiga, T.S.; Morais, C.A. Study of the Zircon Processing Aiming the Recovery of Zirconium and Silica. In Proceedings of the 24th International Mining Congress and Exhibition of Turkey, IMCET 2015, Antalya, Turkey, 14-17 April 2015; pp. 1351-1356.

72. Orhanovic, Z.; Pokric, B.; Füredi, H.; Branica, M. Precipitation and Hydrolysis of Metallic Ions. III. Studies on the Solubility of Yttrium and Some Rare Earth Hydroxides. Croat. Chem. Acta 1966, 38, 269-276.

73. Um, N.; Hirato, T. Dissolution Behavior of $\mathrm{La}_{2} \mathrm{O}_{3}, \mathrm{Pr}_{2} \mathrm{O}_{3}, \mathrm{Nd}_{2} \mathrm{O}_{3}, \mathrm{CaO}$ and $\mathrm{Al}_{2} \mathrm{O}_{3}$ in Sulfuric Acid Solutions and Study of Cerium Recovery from Rare Earth Polishing Powder Waste via Two-Stage Sulfuric Acid Leaching. Mater. Trans. 2013, 54, 713-719. [CrossRef]

74. Chen, W.-S.; Ho, H.-J.; Lin, K.-Y. Hydrometallurgical Process for Tantalum Recovery from Epoxy-Coated Solid Electrolyte Tantalum Capacitors. Materials 2019, 12, 1220. [CrossRef] [PubMed]

75. Clark, R.J.H.; Brown, D.; Bailar, J.C.; Emeléus, H.J.; Nyholm, R. The Chemistry of Vanadium, Niobium and Tantalum: Pergamon Texts in Inorganic Chemistry; Elsevier: Amsterdam, The Netherlands, 2013; Volume 20.

76. Deblonde, G.J.-P.; Chagnes, A.; Bélair, S.; Cote, G. Solubility of niobium(V) and tantalum(V) under mild alkaline conditions. Hydrometallurgy 2015, 156, 99-106. [CrossRef]

77. Deblonde, G.J.-P.; Chagnes, A.; Weigel, V.; Cote, G. Direct precipitation of niobium and tantalum from alkaline solutions using calcium-bearing reagents. Hydrometallurgy 2016, 165, 345-350. [CrossRef]

Publisher's Note: MDPI stays neutral with regard to jurisdictional claims in published maps and institutional affiliations.

(C) 2020 by the authors. Licensee MDPI, Basel, Switzerland. This article is an open access article distributed under the terms and conditions of the Creative Commons Attribution (CC BY) license (http://creativecommons.org/licenses/by/4.0/). 